establishment of a global corporate culture research center, strengthening international cooperation, specializing in developing integrated enterprises, expanding Geely's global vision, and improving global management capabilities and global corporate culture integration capabilities.

\section{CONCLUSION}

This article focuses on the crucial role of corporate culture integration in cross-border mergers and acquisitions. It provides suggestions for international M\&A basis on the case of Geely's acquisition of Volvo. After the M \& M\&A, Geely not only achieved the brand premium and successfully entered the global market with the help of Volvo's advanced technology and mature overseas sales network. In return, Volvo also acquired revitalization and thoroughly stimulating vitality and creativity based on maintaining the original target positioning. If Chinese enterprises want to "go global" and "go stable," they must pay attention to integrating corporate culture, which penetrates all aspects of corporate management and becomes an essential factor affecting the effects of mergers and acquisitions and corporate development. Chinese enterprises need to attach more importance to cultural integration to promote collective force and explore corporate cultural integration which is suitable for internationalization.

\section{REFERENCE}

1.Junichi Kato, Richard Schoenberg. The impact of post-merger integration on the customer-supplier relationship $[\mathrm{J}]$. Industrial Marketing Management, 2014, 43(2) : 335-345

2.Wenxing Sun, Pu Li, Chengcheng Li. Research on Human Resource Integration in Transnational Mergers and Acquisitions for Chinese Enterprises[P]. Proceedings of the 2018 International Conference on Advances in Social Sciences and Sustainable Development (ASSSD 2018), 2018: 522-527.

3.Liu Ang, Fu Shan-na, Xiao Zhen-hong. Study on risk assessment of overseas merger and acquisition knowledge integration based on character-weighted set pair[J]. ClusterComputing, 2019, 22(2): 52-58.

4.Maria E Botchkova. Critical success factors in the post-mergers and acquisitions information technology integrations[D]. Massachusetts Institute of Technology, 2017: 220-224.

5.Hu Ting, Wang Jikang. Do Chinese companies' overseas mergers and acquisitions enhance company value?- Take Geely's acquisition of Volvo as an example[J]. East China Economic Management, 2014, 28(02): 155-159.

6.Liang Yanjun. Cultural Integration in Chinese Enterprises' Overseas Mergers and Acquisitions[j]. Chinese \& Foreign Corporate Culture, 2016(11): 65-67.

7.Zhao Xiaoying. The Value Evaluation of Synergy Effect of Auto Enterprise M\&A[D]. South China University of Technology, 2019.

8.Hofsted insight[EB/OL]. www.hofstedeinsights.com

\title{
STRATEGIC DIRECTIONS FOR THE SUSTAINABLE DEVELOPMENT OF THE REPUBLIC TOGOLESE
}

DOI: 10.31618/ESU.2413-9335.2021.3.85.1329
Malacoubame Kolani,
Hanchar Andrei I.

\section{ABSTRACT}

The transition to sustainable development is impossible without a solution to the country's waste management problem. In addition, the achievement of the objectives of the Togolese Republic's transition strategy towards sustainable development determines the need to meet the main challenges. This is due to the reduction in the amount of Class 2 hazardous waste, represented by used batteries and used battery acid, the types of waste formed in most cases, are caused by people with a waste-producing activity of less than 50 tons per year (about 400 subjects of economic and other activity). Based on the above, we can say that the main priority axes of transition of sustainable development of Togo must respect the condition of greening economic processes, which will improve both the quality and the standard of living of the population, preserve and protect the ecology in the regions. The development of such a direction as agro-ecotourism makes it possible to comply with this requirement and fully comply with the principles of sustainable development. Then, for a more detailed study, we will evaluate the development of agro-ecotourism in the regions.

Keywords: sustainable development, environmental safety, EUROSTAT, emissions of pollutants, recycling, waste management problem, Agro-industrial, tourism activities, wood waste.

The socio-economic state of the Republic of Togo is closely linked to the environmental restrictions that exist in the territory of the West African sub region, which also includes Togo.

The country is characterized by low representation of leading industries such as: mechanical engineering, Metallurgy, electricity, etc. The promising directions of the development of the regions are defined by the Agrofood and tourism activities. The adoption of a sustainable development policy by the state requires the authorities to address important socio-economic issues. The goals of prefectures in the context of environmental safety, which, in turn, determines the transition to innovative production systems, energy consumption, resource conservation and the search for new ways of development of the territory. 
The main priorities of the region, according to strategies of socio-economic development of the Republic by 2025 , indicated in the first stage.

- the formation and development of such groups as agro-industrial, tourism and construction and the second phase includes the activation of more" complex " clusters for regional power, but which can provide a higher rate of economic development: the transport and logistics cluster, the mining cluster, the forest cluster, the alternative energy and small energy cluster.

Togo's goal for the transition to a sustainable regional environment

The development is indicated in the program "commitment to halve poverty by 2025 through inclusive growth and transformation of Agriculture" (Document of the National Strategy for Agricultural and Rural Training in Togo (SNTAR-TOGO) 20162020 ; p. 3), where the main objective is to establish the economic framework for the transition from poverty to poverty.

Development, dynamic development, the economic potential of the country to achieve a decent standard of living of the population on the basis of the principles of self-development, modernization of the economy, efficiency and competitiveness, production taking into account the requirements of greening the economic

Activities related to the preservation of the ecosystem, the implementation of the goals and objectives of the presented strategy will create a platform for developing new innovative approaches to economic and social development, taking into account the characteristics of each region.

We recall that Togo is a country with a high percentage in rural areas, the proportion of the total area of the occupied population is about 60\%, which determines the great importance of rural territories in the development of the Republic [1].

The current situation of rural territories in Togo is characterized by a rather difficult socio-economic situation, however, in our view, it is in the countryside that problems related to climatic conditions arise. The greening of economic activities that define and meet the requirements of sustainable development of territories based on this, we believe that the significant impact on the process of formation of sustainable development strategy in Togo is found in the rural territories of the areas that are produced food products its and respecting international environmental standards.

The natural conditions of the standard of living have a positive effect on the psycho-emotional state of a person, which, in general, personifies the countryside as a promising territory for the sustainable development of the country.

Thus, in our opinion, important reserves, necessary for the transition to sustainable development of the country. The rural development of the region depends on regional authorities and sustainable development programs of rural territories based on the principles of self-development.

The self-sufficiency of the country's rural economy will be ensured by the creation of greater reproduction of intra-regional sources. This is a better use of the potential of resources, while compensating for regional expenses.

The transition to the trajectory of sustainable development involves not only the creation of innovative local products, using progressive technologies of resource conservation, but also to the reduction of the high level of waste production and consumption ; characteristic of developing countries (India, Nigeria, Ghana, Mexico etc.).

The production of municipal waste in the European Union is monitored annually by EUROSTAT. These are defined as household waste and assimilated without debris and rubble. Within the European Union of 28, in 2018, they represent 250.3 million tons in Europe, including 35 million tons for France, or $4883 \mathrm{~kg}$ per capita. However, this average hides strong disparities $(272 \mathrm{~kg} / \mathrm{hab}$ in Romania, 527 $\mathrm{kg} / \mathrm{hab}$ in France, $766 \mathrm{~kg} / \mathrm{hab}$ in Denmark), with each country having its own organization in terms of waste management (including or not including waste produced by private and public establishments) [2].

Significant disparities exist between countries, linked to their own characteristics (institutional, industrial, demographic), but also the quality of their information system (table 1).

Table 1.

Waste generation in the European Union in 2016 [3]

\begin{tabular}{|c|c|c|c|}
\hline In thousands of tons & Total production & of which dangerous & Total (tonnes / inhabitants) \\
\hline European Union - 28 countries & 2536981 & 100742 & 5,0 \\
\hline Germany & 400072 & 23039 & 4,9 \\
\hline France & 322685 & 11010 & 4,8 \\
\hline Uk & 277255 & 6087 & 4,2 \\
\hline Poland & 182006 & 1917 & 4,8 \\
\hline Romania & 177563 & 652 & 9,0 \\
\hline Italy & 163995 & 9707 & 2,7 \\
\hline Sweden & 141626 & 2379 & 14,3 \\
\hline Netherlands & 141024 & 5134 & 8,3 \\
\hline Spain & 128959 & 3184 & 2,8 \\
\hline Finland & 122869 & 2388 & 22,4 \\
\hline Bulgaria & 120508 & 13328 & 6,9 \\
\hline Greece & 72358 & 504 & 5,7 \\
\hline Lgium & 63152 & 3813 & 7,0 \\
\hline Austria & 61225 & 1261 & \\
\hline
\end{tabular}




\begin{tabular}{|c|c|c|c|}
\hline Czechia & 25381 & 1089 & 2,4 \\
\hline Estonia & 24278 & 9682 & 18,5 \\
\hline Denmark & 20982 & 2011 & 3,7 \\
\hline Hungary & 15938 & 457 & 1,6 \\
\hline Ireland & 15252 & 534 & 3,2 \\
\hline Portugal & 14739 & 835 & 1,4 \\
\hline Slovakia & 10607 & 496 & 2,0 \\
\hline Luxembourg & 10130 & 427 & 17,4 \\
\hline Lithuania & 6644 & 176 & 2,3 \\
\hline Slovenia & 5494 & 124 & 2,7 \\
\hline Croatia & 5278 & 174 & 1,3 \\
\hline Latvia & 2533 & 66 & 1,3 \\
\hline Cyprus & 2463 & 159 & 2,9 \\
\hline Malta & 1966 & 134 & 4,3 \\
\hline
\end{tabular}

Source: Eurostat, January 2020.

Table 2.

Evolution of municipal waste production per capita

\begin{tabular}{|c|c|c|c|c|c|c|c|c|c|c|c|c|c|c|}
\hline & & & & & & & & & & & & & & \\
\hline In kg / hab & 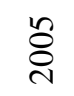 & ஜ্ণ & ڤ్రి & 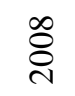 & 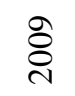 & $\stackrel{\circ}{\stackrel{0}{\circ}}$ & $\overrightarrow{\widetilde{d}}$ & $\stackrel{\sim}{\stackrel{N}{N}}$ & $\stackrel{m}{\vec{\nu}}$ & $\stackrel{+}{\vec{D}}$ & $\frac{n}{\tilde{c}}$ & $\stackrel{0}{\circ}$ & 홍 & $\stackrel{\infty}{\vec{c}}$ \\
\hline France & 529 & 535 & 542 & 538 & 534 & 534 & 534 & 527 & 520 & 517 & 516 & 521 & 526 & 527 \\
\hline Europe & 515 & 522 & 524 & 521 & 511 & 504 & 498 & 486 & 479 & 478 & 480 & 487 & 487 & 488 \\
\hline
\end{tabular}

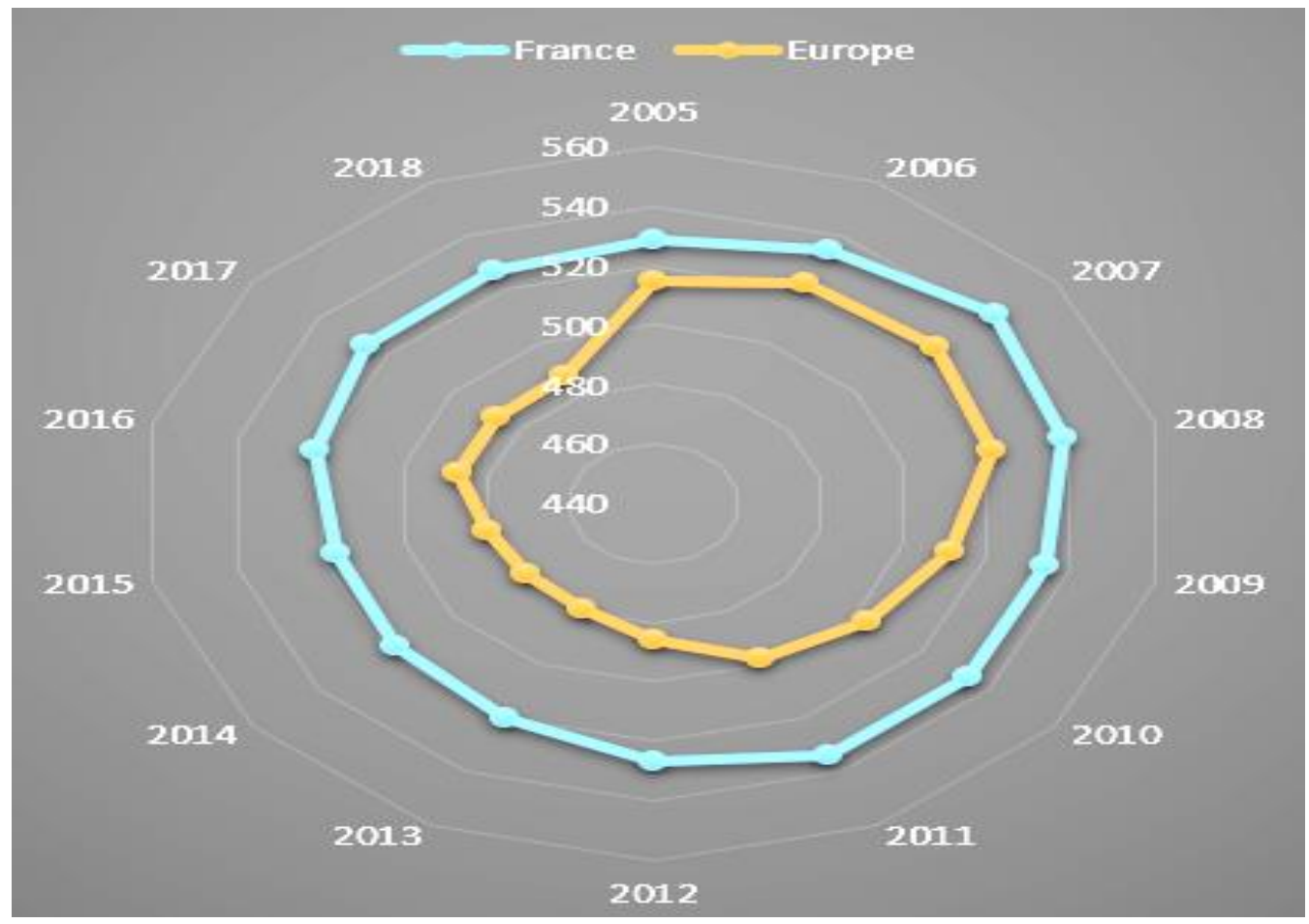

Figure 1 -Assessment of municipal waste production per capita

Field: Excluding cuttings and rubble sent to landfills

Source: Ademe. SDES; Eurostat January 2020

Currently, in Togo, the recycling of plastic waste significantly reduces the total amount of plastic waste, as well as the problems related to environmental pollution and public insalubrity. It is a socio-economic development and sanitation project that has allowed in place:

- the first structure for recycling plastic waste in paving stones in Togo;
- the successful implementation of a recycling and transformation of plastic waste as a model for economic development and sanitation;

- ensure the collection and storage of used plastic bags in the communities (of 1500 tons annually in the city of Lomé);

- strengthen communities to fight against public insalubrity and pollution in neighborhoods (50 environmental clubs are set up annually within 
schools). Thus promotes the contribution to local economic development through the support of a network of private initiatives of simple collection of this plastic waste;

- contribution to the development of the national economy;

- processing and manufacturing of paving stones;

- job creation for youth;

- promotion of grassroots development.

Analysis of the first results shows: purchase of important plastic waste (the observation is that the message of awareness begins by reaching the target population and the collection of plastic waste does not stop increasing in tonnage; paradoxically, we have a smaller budget for collectors); multiplication of collection points (view the distance that collectors (the population) travel to the points of purchase).

The heads of the other neighborhood development committees request the installation of collection points in Lomé as well as in the interior of the country. Environmental NGOs have a strategy of extending the project of collection and purchase of used plastic bags in order to cover the whole project inward by installing cells, and to collaborate with other associations for more ecological impact. Achievability. It should be emphasized that the impacts of plastic bags prevail in many cities, which is a common feature of poor countries.

An organizational mechanism is put in place for the execution of the project. Bring grassroots development associations to promote sustainable development systems and protect the environment. Continue capacity building and professionalization of environmental institutions [4].

It follows from the information provided that the increase in high-risk waste, this fact is related to radiation; for example, the service life of a capacitor in the facilities of (Trichlorodipheny capacitors), which was confirmed in the report of the Russian ministry.

The increase in waste of hazard class 5 occurred due to the increase in the number of self-propelled rocks formed during the operation of coal deposits (LLC "Coal Cutting", LLC "bayin-Zurhe").

Changes related to the reduction of the remaining waste, the order of the federal service for supervision in the field of the environment of 14.11.2011 g. No. 828 "On the organization of work on the implementation of the federal statistical office of observation form No. 2TP (waste) and the formation of official statistical information," collection of forms of the federal statistical office of observation No. 2-TP (waste) for 2011 was produced with legal entities and individual entrepreneurs, whose annual amount of waste is 50 tons and more. This is due to the reduction in the amount of hazardous waste of class 2, represented by used batteries and used battery acid, types of waste formed in most cases, people with a waste amount of less than 50 tons per year (about 400 subjects of economic activity and others.

Table 3.2.

Air emissions of pollutants from stationary sources by type of economic activity (thousands of tons) [5]

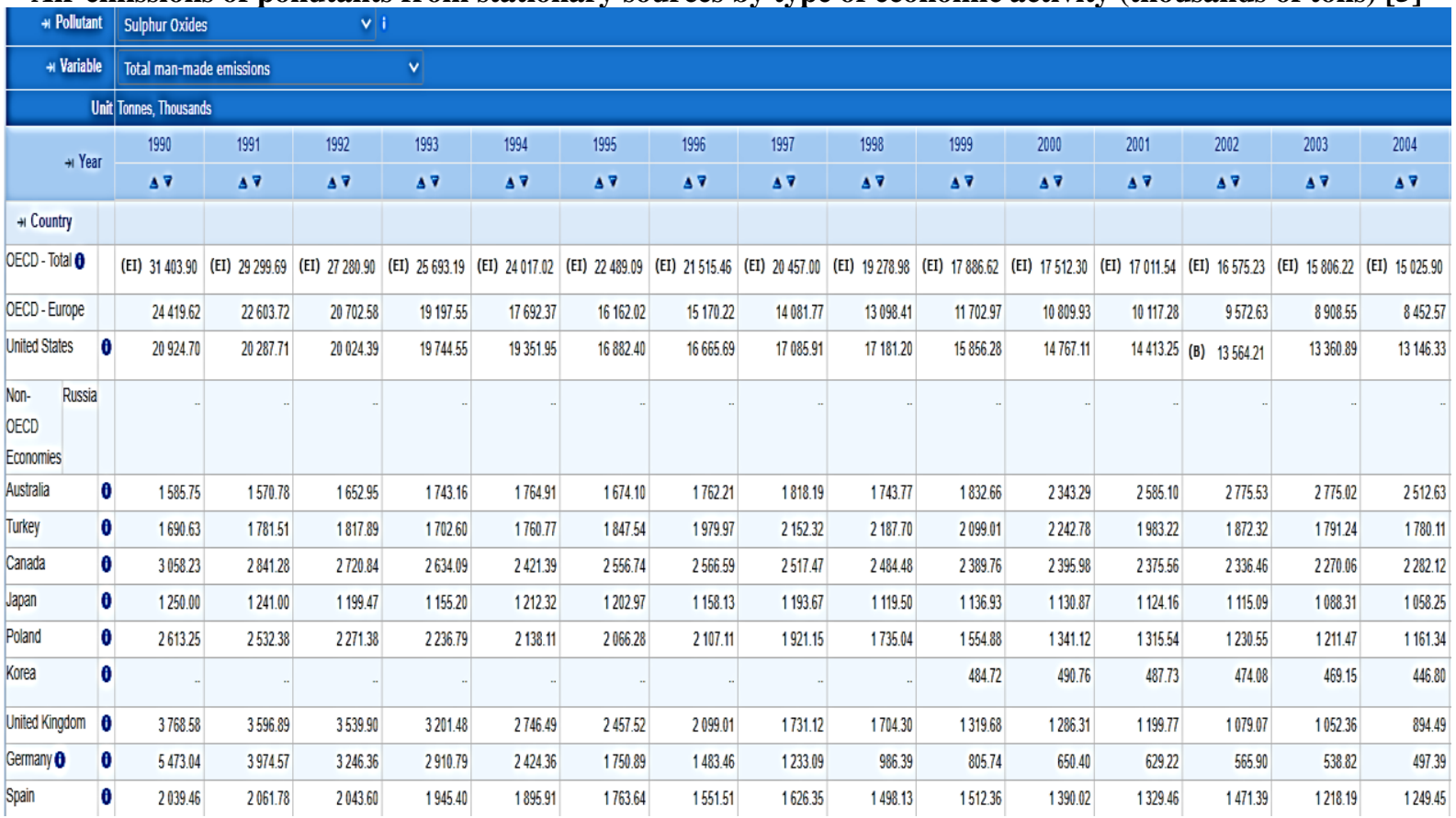

According to the report, the decrease in waste production to the 3-th class of danger caused by a reduction in the volume of repair to track work on the objects of the joint stock company open type "railways" (type of waste "Wooden railway sleepers, impregnated with antiseptics means, the past and marriage" - 6000 tons), the redevelopment of cement production of LLC "cement plant" (type of waste Other mineral solids cement" - 63000 tons).

Reduction in the production of class 4 waste caused by the translation of the type of waste " Natural processing waste clean wood not contaminated with hazardous substances (wood waste)" to the open type joint stock company selenginsky cellulosic and cardboard "into raw and secondary materials. The 
annual production of corodrevesina is more than 30,000. 0 tons.

Thus, it can be established that the share of waste of enterprises engaged in productive and economic activities accounts for a significant part of the total volume of waste, which confirms the structure of waste presented by official statistical bodies.

However, the total number of unauthorized landfills in Russia and their area decreased by seven times between 2010 and 2013, that is, from 1018 units on an area of 441 hectares to 147 on 69 hectares, according to data provided by the Ministry of Natural resources of the Republic .

The problem of waste is therefore closely linked to the principles of sustainable development and inversely proportional. We believe that the transition to sustainable development is impossible without a solution to the country's waste management problem.

In addition, the achievement of the objectives of the transition strategy of the Togolese Republic on the path of sustainable development determines the need to meet the following main challenges:

1. Ensure the economic and social growth of the population taking into account the environmental constraints of the territory.

2. Implementation of the structural orientation of the country's economy taking into account the environmental factor (this requires the development of industries that most contribute to the preservation and improvement of the environment in the country, while allowing rational use of the territory's resources to meet socio-economic needs).

3. Raising the standard of living of the rural and urban population (by creating an environment conducive to rural development and increasing employment in rural areas, reducing the outflow of the urban population, reducing social inequalities, and infrastructural development of rural territories).

To preserve the ecological potential of the region as a basis for the socio-economic development of future generations. Increase ecological, economic and social capital for future use. The sustainable development strategy is largely based on the human factor. Effective management decisions made by humans must be fully balanced with the environment. Education is therefore one of the elements of a new identity focused on an ecological value system rather than the values of a consumer society. The formation of spiritual and moral values focused on the further development of civilization.

Based on the above, the formation of sustainable development in Togo should be based on solving this set of problems.

Create a climate conducive to rural development. Togo will develop agricultural colonies as one of the strategic units of sustainable development. The rural development program should primarily integrate the formation of rural society and infrastructure, which will have a direct impact on the quality of life of the local population and will form an investment in the attractiveness of the territory. The development of social infrastructure, is a situation in decline after the years of reconstruction and crisis would not only enhance the attractiveness of the village, but would also create new jobs, thus creating rural jobs and, consequently, stable incomes.

In order to reduce the disproportionate development of rural and urban areas to instill the autonomy of the village in relation to the city, it is necessary to develop measures for the direct cooperation of these actors. Cooperation on mutually beneficial conditions for the village and the city will not only reduce the inequality between rural and urban populations, but also creates the prerequisites for the development of socio-economic space between two given territorial units. The use of cultural, historical, picturesque heritage, with the capacity of village allows us to develop proposals in the field of rural development. Involvement in the production process allows the use of not only material capital, labor capital, but also intellectual capital. This in turn helps to reduce the social tensions that characterize rural areas due to the lack of jobs, incomes and total non-demand from society.

Solving socio-economic problems of rural territories in the country, largely focuses on the use and development of resources available to the territory.

A balanced use of resources, combined with sustainable development planning, will allow priority to be set for each region based on available capacity.

High environmental conservation requirements should be a priority for the development of environmentally friendly industries. We can systematize the main economic activities of the Republic of Belarus greening criteria. For example, in our opinion, the species environment can be attributed to the development of an agro-food and tourist complex.

As shown by the analysis of Tourism development programs in Togo, this industry Co-directed with the vector of sustainable development of the community, which is in line with the integration into the sustainable development priorities of the regions.

The choice of the agro-food cluster as one of the elements of sustainable development. Development implies not only the presence of the agrarian character of production in the country, but also the possibility of creating natural and environmentally friendly products, clean products, not in industrial enterprises, but in households [6].

Based on the above, we can conclude that the main priority axes of transition of sustainable development of Togo must be in accordance with the condition of greening economic processes, which will both improve the quality and standard of living of the population, preserve and protect the ecology in the regions. The development of such a direction as Agro-ecotourism makes it possible to comply with this requirement and fully comply with the principles of sustainable development. Then, for a more detailed study, we will evaluate the development of Agro-ecotourism in the regions.

\section{Bibliographic list}

1. Togo / Perspective Monde [Electronic resource]. 
https://perspective.usherbrooke.ca/bilan/tend/TGO/fr/ SP.URB.TOTL.IN.ZS.html (access date: 25.04.2021).

2. Eurostat / Municipal waste statistics / [Electronic resource]. https://ec.europa.eu/eurostat/statisticsexplained/index.php/Municipal_waste_statistics (access date: 25.04.2021).

3. Waste generation / In 2016, the highest absolute levels of waste generation [Electronic resource]. URL: https://www.eea.europa.eu/airs/2018/resourceefficiency-and-low-carbon-economy/waste-generation (access date: 25.04.2021).

4. THEbmj / Analysis Accelerating Action on Sustainable Development Goals / [Electronic resource]
- URL: https://www.bmj.com/content/365/bmj.12269 (access date 25.04.2021).

5. Air emissions of pollutants from stationary sources by type of economic activity [Electronic resource] - $\quad$ URL: https://stats.oecd.org/viewhtml.aspx?datasetcode=AIR _EMISSIONS\&lang=en (access date 25.04.202).

6. Цебро Т.В., Дорошкевич И.Н. Международный опыт в сфере формирования и регулирования рынка экологически чистой продукции / Т.В. Цебро, И.Н. Дорошкевич // Экономика. Бизнес. Финансы. - 2020. № 7 . C. 19-23.

УДК: 657.9

\title{
ОЦЕНКА, ПРИЗНАНИЕ И АНАЛИЗ ОБОРОТНЫХ АКТИВОВ ПРЕДПРИЯТИЯ В СООТВЕТСТВИИ С МСФО И ПБУ (ФСБУ)
}

\author{
DOI: $10.31618 /$ ESU.2413-9335.2021.3.85.1328 \\ Каращенко Виктория Владимировна, \\ Доцент кафедры «Экономика и управление», к.э.н., \\ Гончарова Анастасия Игоревна, \\ Студент 5 курса, направление 38.03.01 «Экономика» \\ Шахтинский автодорожный институт (филиал) ЮРГПУ (НПИ) им. М.И. Платова
}

2. Waxmbl

\section{АННОТАЦИЯ}

В настоящей статье рассматривается процесс оценки, признания и анализа оборотных активов предприятия в разрезе МСФО и ПБУ (ФСБУ). Прослеживается значительное рассмотрение оценки активов в системе МСФО. Авторами делается сравнение признания, оценки и анализа оборотных активов по международным и российским стандартам.

В заключении рассматривается влияние занижения и завышения стоимости активов и методов оценки.

\section{ABSTRACT}

This article examines the process of assessing, recognizing and analyzing the current assets of a company in the context of IFRS and RAS (FSBU). There is a significant consideration of the valuation of assets in the IFRS system. The authors compare the recognition, assessment and analysis of current assets according to international and Russian standards.

Finally, the impact of undervaluation and overvaluation of assets and valuation methods is examined.

Ключевые слова: оборотные активы, запасы, денежные средства, дебиторская задолженность, анализ, МСФО, ПБУ, ФСБУ.

Keywords: current assets, inventory, cash, accounts receivable, analysis, IFRS, RAS, FSBU.

Для оптимизации управления предприятием актуальным является выбор методов оценки стоимости оборотных активов, приближающей к справедливой стоимости. Признание оборотных активов (включение в баланс) зависит от надежной оценки актива. При анализе первостепенным является изучение степени ликвидности оборотных активов.

В учетной и аналитической практике выстраивается цепочка: оценка -признание анализ. В системе МСФО оценка является важнейшим процессом. В системе ПБУ (ФСБУ) оценке отводится меньшая роль.

Оборотные активы представляют собой важнейшую экономическую категорию, отражающую стоимостную оценку оборотных средств предприятия, состав и структура которых влияют на устойчивость его финансового положения. Кроме того, оборотные активы являются одной из главных составляющих ресурсного потенциала организации. Средства, входящие в состав оборотных активов, должны быть компенсированы за один оборот, то есть за короткий промежуток времени [1].

Согласно МСФО, актив представляет собой pecypc, который находится под контролем предприятия в результате прошлых событий, от которого ожидается поступление экономической выгоды на предприятии в будущем.

Перейдем к признанию оборотных активов.

Международные стандарты финансовой отчетности обязывают предприятие именовать актив оборотным в следующих случаях:

предполагается реализация или использование актива в его обычном операционном цикле;

- удержание такого актива происходит только для цели торговли; 